www.regberry.ru/nalogooblozhenie/ESHN.

4. Кузнещова О.Н. Учетно-аналитическое обеспечение расчетов по единому сельскохозяйственному налогу // Экономика и предпринимательство. -2015. № 5-1 (58-1). - С. 445-448.

5. Налоговый кодекс Российской Федерации (часть вторая). Глава 26.1. // СПС «Консультант Плюс». - Режим доступа: http://www.consultant.ru/document/cons doc_LAW_28165/ 6e115134a13db9e972d7d94237b5ed95f $\mathrm{cb} 0 \overline{0} \mathrm{~d} 14 /$.

6. О внесении изменений в части первую и вторую Налогового кодекса Российской Федерации и отдельные законодательные акты Российской Федерации: [Федер. закон: принят Гос. Думой 27 ноября 2017 г. N 335-Ф3 (последняя редакция)] // СПС «Консультант Плюс». - Режим доступа: http://www.consultant.ru/ document/cons_doc_LAW_283495/.

7. Ставка налога на прибыль для сельхозпроизводителей // Экономика и жизнь. - Режим доступа: https:// www.eg-online.ru/news/345816/.

8. Суханова И.Ф., Лявина М.Ю. Совершенствование системы господдержки животноводства как инструмен- та политики импортозамещения // Аграрный научный журнал - 2017. - № 12. - С. 92-95.

9. Филиппова А.А. Единый сельскохозяйственный налог // Новая наука: Современное состояние и пути развития. - 2017. - Т. 1. - № 3. - С. 165-168.

10. Шевцова Т.П., Белокопытов А.В. Единый сельскохозяйственный налог как инструмент регулирования эффективности сельскохозяйственного производства // Вестник Российского государственного аграрного заочного университета. - 2016. № 21 (26). - С. 94-99.

Суханова Ирина Федоровна, д-р экон. наук, проф. кафедры «Маркетинг и внешнеэкономическая деятельность», Саратовский государственный аграрный университет имени Н.И. Вавилова.

Россия. 410012, г. Саратов, Театральная пл., 1.

Тел.: (8452) 23-72-60.

Алиев Максим Игоревич, канд. экон. наук, финансовый менеджер, ООО «Торговая группа Союз». Россия.

180004, г. Псков, Железнодорожная ул., 43.

Тел.: (8112) 72-23-26.

Ключевые слова: налогообложение; единый сельскохозяйственный налог; налог на добавленную стоимость.

\title{
DEVELOPMENT OF AGRICULTURAL AND PROCESSING ENTERPRISES: PROBLEMS AFTER CHANGES OF FISCAL LEGISTATION IN RF
}

Sukhanova Irina Fedorovna, Doctor of Economic Sciences, Professor of the chair "Marketing and International Economic Activity", Saratov State Agrarian University named after N.I. Vavilov. Russia.

Aliev Maksim Igorevich, Candidate of Economic Sciences, financial manager of LLC «Torgovaya gruppa Soyuz». Russia.

Keywords: taxation; unified agricultural tax; value added tax.
Various options of systems of the taxation applied in the enterprises of agro-industrial complex are considered. The analysis of consequences of changes of the fiscal legislation regarding the system of collection of a unified agricultural tax is made. Macroeconomic consequences of introduction of system of the taxation with use of a value added tax by the principle "from the field to a counter" are studied.

удк 338.43

\section{АНАЛИЗ ОЦЕНКИ ЭФФЕКТИВНОСТИ РЕАЛИЗАЦИИ ГОСУДАРСТВЕННОЙ ПРОГРАММЫ РАЗВИТИЯ СЕЛЬСКОГО ХОЗЯЙСТВА В РОССИИ}

\author{
УМЕРОВА Светлана Александровна, Саратовский социально-экономический институт \\ (филиал) РЭУ им. Г.В. Плеханова
}

САНИНСКИЙ Сергей Александрович, Саратовский социально-экономический институт (филиал)РЭУ имени Г.В. Плеханова

Анализируется Государственная программа развития сельского хозяйства и регулирования рынков сельскохозяйственной продукиии, сыръя и продоволъствия на 2013-2020 годы (далее - Государственная программа), а в том числе методология оценки эффективности указанной программы. Выявлены недостатки методики оценки эффективности Государственной программы, связанные с субъективностью имеющихся нормативов; отсутствием использования в расчетах корреляционно-регрессионных моделей, позволяющ,их выявить и учесть зависимость полученнъх результатов от изменения отдельнъх факторов и условий среды; неоптимальным расчетом комплексного показателя эффективности реализации Государственной программы. Авторы предлагают ранжировать основные индикаторы Государственной программы по характеристике выражаемых явлений и процессов: экономическая эффективность, социальная эффективность и бюджетная эффективность, и признакам, раскрывающим природу измеряемого объекта: количественные показатели и качественные показатели. Рекомендуется внести соответствующие изменения в методику расчета основных индикаторов Государственной программы.

Введение. Агропромышленный комплекс важнейший межотраслевой комплекс национальной экономики, обеспечивающий удовлетворение потребностей в продовольственных товарах как основы жизнедеятельности людей и воспроизводства трудовых ресурсов, потребительских това- рах из сельскохозяйственного сырья и продукции производственного назначения и в конечном итоге - продовольственную безопасность России [3]. Агропромышленный комплекс также обеспечивает самозанятость населения, развитие сельских территорий, сохранение сельского уклада жизни, 
историко-культурного потенциала российской деревни, достижение продовольственной независимости страны, ее политическую и экономическую устойчивость и конкурентоспособность [4].

В связи с вышеизложенным органы государственной власти рассматривают развитие АПК как приоритетное, стратегическое направление деятельности государства. Государственное регулирование агропромышленного комплекса обеспечивает преодоление несовершенства рыночного механизма, макроэкономической нестабильности на внешнем и внутреннем рынках, минимизацию негативных природно-климатических факторов, протекционизм, дифференцированный подход по отношению к регионам, стимулирование эффективных товаропроизводителей. Среди методов государственного регулирования агропромышленного комплекса значительную роль в настоящее время играет программирование [9].

Неотъемлемой составляющей применения программно-целевого подхода к развитию АПК является оценка полученных в ходе реализации государственной программы результатов [10, с. 89].

методика исследований. Теоретической и методологической основой исследования являются учебные пособия и монографические исследования по вопросам государственного регулирования национальной экономики, аграрной экономики, экономике и управлению в АПК, публикации в периодической печати и материалы международных и всероссийских конференций, посвященные проблемам государственного программирования в целом и разработке и реализации государственных программ развития АПК в частности, а также указы Президента РФ, федеральные законы РФ, постановления и распоряжения Правительства РФ, приказы и распоряжения Министерства экономического развития РФ и Министерства сельского хозяйства РФ в сфере государственного программирования и развития агропромышленного комплекса Российской Федерации и его ведущей отрасли - сельского хозяйства. При проведении исследования в целях достижения научных результатов использовались такие общенаучные методы и приемы познания, как анализ, синтез, группировка, аналогия, систематизация, обобщение, ситуационный, сравнительный, комплексный и системный подходы, а также специальные методы и приемы статистического и экономического анализа с использованием программно-вычислительных средств.

Результатъи исследований. Авторами проведен анализ Государственной программы развития сельского хозяйства и регулирования рынков сельскохозяйственной продукции, сырья и продовольствия на 2013-2020 гг. (далее - Государственная программа), утвержденной Постановлением Правительства Российской Федерации от 14 июля 2012 г. № 717 как основополагающего докумен- та программирования в АПК, который разработан в соответствии с положениями Федерального закона от 29 декабря 2006 г. № $264 \ll$ « развитии сельского хозяйства», Концепцией долгосрочного социально-экономического развития Российской Федерации на период до 2020 г., Доктриной продовольственной безопасности Российской Федерации, Стратегией развития пищевой и перерабатывающей промышленности Российской Федерации на период до 2020 г., Концепцией устойчивого развития сельских территорий Российской Федерации на период до 2020 г., Стратегией устойчивого развития сельских территорий Российской Федерации на период до 2030 г., а также положениями других федеральных и ведомственных целевых программ, связанных с решением проблем развития агропромышленного комплекса страны и обеспечением ее продовольственной безопасности [6].

Рассматриваемая Государственная программа определяет цели, задачи и основные направления развития сельского хозяйства и регулирования агропродовольственного рынка, финансовое обеспечение и механизмы реализации предусмотренных мероприятий и показатели их результативности; предусматривает комплексное развитие всех отраслей и подотраслей, а также сфер деятельности агропромышленного комплекса с учетом членства России во Всемирной торговой организации, ее участия в Евразийском экономическом союзе и других региональных объединениях на экономическом пространстве СНГ [7].

Оценка эффективности Государственной программы осуществляется в соответствии с Методикой оценки эффективности Государственной программы развития сельского хозяйства и регулирования рынков сельскохозяйственной продукции, сырья и продовольствия на 2013-2020 гг., утвержденной Приказом Министерства сельского хозяйства Российской Федерации от 07.07.2017 г. № 333 (далее - Методика) [8].

Оценка эффективности реализации Государственной программы предполагает расчет таких показателей, как степень реализации основных мероприятий подпрограмм и федеральных целевых программ, степень соответствия запланированному уровню расходов, эффективность использования средств федерального бюджета, степень реализации подпрограммы и федеральной целевой программы, эффективность реализации подпрограммы и федеральной целевой программы. Лишь на заключительном этапе процесса оценки эффективности реализации Государственной программы в Методике представлены формулы для расчета степени достижения плановых значений показателей (индикаторов), характеризующих достижение целей и выполнения задач Государственной программы.

Таким образом, согласно Методике эффективность Государственной программы складывается 
из суммарной оценки достижения уровня каждого из основных показателей (индикаторов), которые обозначены в паспорте Государственной программы. Показатели рассчитываются по отношению к отчетному периоду, а также осуществляется расчет нарастающим итогом к базовому периоду.

Недостатком используемой Методики является определенная субъективность имеющихся нормативов, а также отсутствие корреляционно-регрессионных моделей, которые позволили бы описать зависимость полученных в итоге результатов от изменения отдельных факторов и условий. Также несовершенным является сведение всей системы показателей к комплексному значению без учета достаточно высокой разнородности данных показателей и, соответственно, их весовых значений [11, с. 154].

В связи с этим для осуществления предварительной (до начала реализации программы), периодической (в процессе реализации программы, ежегодно) и итоговой (после окончания реализации программы) оценки эффективности Государственной программы представляется рациональным основные показатели, отраженные в паспорте, ранжировать по характеристике сущности выражаемых явлений и процессов: экономическая эффективность, социальная эффективность и бюджетная эффективность, а также признакам, раскрывающим природу измеряемого объекта: количественные показатели и качественные показатели.

Показатели экономической эффективности Государственной программы предусматривают оценку прироста количественных показателей - производства продукции различных сфер, отраслей и подотраслей АПК и главного итогового индикатора работы АПК в целом - конечного продукта АПК, а также рост качественных (расчетных) показателей - соотношения конечного продукта АПК с общим количеством населения, численностью работников АПК, суммой производственных затрат АПК, стоимостью основных производственных фондов, объемом внутреннего потребления $[2$, с. 56].

Среди показателей экономической эффективности государственных программ развития АПК необходимо выделить:

конечный продукт АПК;

стоимость конечного продукта АПК в расчете на душу населения;

стоимость конечного продукта АПК в расчете на среднегодовую численность работников АПК (производительность труда в АПК);

стоимость конечного продукта АПК в расчете на сумму производственных затрат АПК;

стоимость конечного продукта АПК в расчете на стоимость основных производственных средств АПК (фондоотдача);

уровень самообеспечения территории основными видами продукции АПК (отношение произ- водства к внутреннему потреблению).

Показатели социальной эффективности Государственной программы предполагают оценку улучшения социальной среды жизнедеятельности в сельской местности (сохранение существующих и создание новых, в том числе высокотехнологичных рабочих мест, повышение заработной платы, строительство жилых домов, в том числе для молодых семей и молодых специалистов, а также детских садов и общеобразовательных школ, фельдшерско-акушерских пунктов и офисов врачей общей практики, клубов и домов культуры, обновление жилищно-коммунальной инфраструктуры - электроснабжения, водоснабжения и газоснабжения).

Показатели бюджетной эффективности Государственной программы предусматривают оценку прироста количественных показателей - объема налоговых поступлений в бюджеты всех уровней, в том числе по разным уровням, и объема привлеченных внебюджетных источников, а также рост качественных (расчетных) показателей - соотношения бюджетных с частными инвестициями и со стоимостью произведенной продукции [5].

К показателям бюджетной эффективности государственных программ развития АПК необходимо отнести:

объем налоговых поступлений в бюджеты всех уровней от АПК;

объем привлеченных внебюджетных источников в АПК;

соотношение бюджетных и частных инвестиций в АПК;

расходы бюджетов всех уровней на АПК в расчете на один рубль произведенной продукции АПК.

В рамках оценки эффективности реализации Государственной программы оптимальным является расчет показателей (индикаторов) именно в разрезе представленных групп показателей с использованием методов экономико-математического моделирования с дальнейшим отражением полученной информации в Национальном докладе о ходе реализации Государственной программы [1]. Данный доклад ежегодно в срок до 15 мая представляется Министерством сельского хозяйства Российской Федерации. Однако в настоящее время, несмотря на значительный объем и полноту представленных направлений (например, развитие отраслей сельского хозяйства, стимулирование инвестиционной деятельности в АПК, реализация приоритетного проекта «Экспорт продукции АПК», техническая модернизация АПК и т.д.), информация в докладе не является исчерпывающей в части оценки эффективности как отдельных подпрограмм и федеральных целевых программ, так и Государственной программы в целом [12].

Заключение. Полученные в результате исследования разработки позволят оптимизировать инструментально-методическое обеспечение про- 
граммирования в АПК. Использование авторских предложений по совершенствованию оценки эффективности реализации Государственной программы будет способствовать получению более объективных результатов и усилению действенности государственного регулирования агропромышленного комплекса. Это, в свою очередь, обеспечит устойчивое развитие агропромышленного комплекса и повышение конкурентоспособности национальной продукции на внутреннем и внешнем рынках.

\section{СПИСОК ЛИТЕРАТУРЫ}

1. Азизова М.М. Совершенствование системы государственного регулирования региональным АПК в современных условиях хозяйствования // Вопросы структуризации экономики. - 2016. - № 4. C. $28-30$.

2. Голубков Е.П. Программно-целевой метод планирования: Учеб. пособие. - М.: МИНХ, 1979. - 80 с.

3. Киреева Н.А, Санинский С.А. К вопросу о продовольственной безопасности России // Международный сельскохозяйственный журнал. - 2016. № 3. - C. 59-63.

4. Киреева Н.А., Сухорукова А.М. Обеспечение экономического суверенитета России в агропродовольственной сфере: тенденции, проблемы, инструменты // Аграрный научный журнал. - 2017. - № 1. - С. 66-74.

5. Медведева Л.Н., Куприянова С.В., Медведев А.В. Программно-целевой подход в управлении АПК: показатели эффективности и реализуемости государственных программ // Тенденции и закономерности развития АПК России: национальный и международный аспекты: материалы Междунар. науч.-практ. конф. Ростов н/Д., 2017. - С. 329-335.

6. О Государственной программе развития сельского хозяйства и регулирования рынков сельскохозяйственной продукции, сырья и продовольствия на 2013-2020 годы: Постановление Правительства РФ от 14 июля 2012 г. № 717. - Режим доступа: http:// base.garant.ru/70210644/.

7. О ходе и результатах реализации в 2017 году Государственной программы развития сельского хозяйства и регулирования рынков сельскохозяйс- твенной продукции, сырья и продовольствия на 2013-2020 годы: Национальный доклад: утв. Распоряжением Правительства Российской Федерации от 28.04.2018 № 808-p. - Режим доступа: http://base. garant.ru/80392641/.

8. Об утверждении методики оценки эффективности Государственной программы развития сельского хозяйства и регулирования рынков сельскохозяйственной продукции, сырья и продовольствия на 2013-2020 годы, утвержденной постановлением Правительства Российской Федерации от 14 июля 2012 г. № 717: Приказ Министерства сельского хозяйства Российской Федерации от 07 июля 2017 г. № 333. - Режим доступа: http://base.garant. $\mathrm{ru} / 53692532 /$.

9. План действий Министерства сельского хозяйства Российской Федерации на 2016-2021 годы: утв. Министерством сельского хозяйства Российской федерации 25.05.2016 г. - Режим доступа: http://base.garant.ru/63581782/.

10. Райзберг Б.А., Лобко А.Г. Программно-целевое планирование и управление: учебник. - М.: ИНФРА-M, 2002. - 428 c.

11. Смирнов И.В. Совершенствование механизмов государственного регулирования агропромышленного комплекса России / Федеральное гос. автономное образовательное учреждение высш. проф. образования «Российский экономический университет им. Г.В. Плеханова». - М., 2015. - 277 с.

12. Официальный сайт Министерства сельского хозяйства Российской Федерации. - Режим доступа:http://mcx.ru/.

Умерова Светлана Александровна, аспирант кафедры «Национальная экономика и государственное и муниципальное управление», Саратовский социально-экономический институт (филиал) РЭУ им. Г.В. Плеханова. Россия.

Санинский Сергей Александрович, $\partial-p$ экон. наук, проф., зав. кафедрой «Маркетинг, экономика предприятий и организаций», Саратовский социильно-экономический институт (филиал) РЭУ им. Г.В.Плеханова. Россия.

410003, г. Саратов, ул. Радищева, 89.

Тел.: (8452) 21-17-77.

Ключевые слова: программно-целевой подход; программы; агропромышленный комплекс; эффективность; совершенствование.

\section{ANALYSIS OF ESTIMATION OF EFFICIENCY OF REALIZATION OF STATE AGRICULTURAL DEVELOPMENT} PROGRAM IN RUSSIA

Umerova Svetlana Aleksandrovna, Post-graduate Student of the chair "National Economy and State and Municipal Administration", Saratov Socio-Economic Institute (branch) of Federal Budgetary State Educational Institute of Higher Education. Russian Economic University named after G.V. Plekahnov. Russia.

Saninskiy Sergey Aleksandrovich, Doctor of Economic Sciences, Professor, Head of the chair "Marketing, Economics of Enterprises and Organizations", Saratov Socio-Economic Institute (branch) of Federal Budgetary State Educational Institute of Higher Education. Russian Economic University named after G.V. Plekahnov. Russia.

Keywords: program-target approach; programs; agro-industrial complex; efficiency; improvement.

The author of the article considers the State Program for the Development of Agriculture and Regulation of the Markets of Agricultural Products, Raw Materials and Food for 2013-2020 (hereinafter referred to as the State Program), and in particular analyzes the methodology for assessing the effectiveness of this State Program. In the course of the research, the author identified shortcomings in the methodology for assessing the effectiveness of the State Program, related to the subjectivity of existing standards; the lack of use in the calculation of correlationregression models, allowing to identify and take into account the dependence of the obtained results on the change of individual factors and environmental conditions; a non-optimal calculation of the complex indicator of the effectiveness of the implementation of the State Program. In this regard, the author finds it necessary to rank the main indicators of the State program in terms of the nature of the phenomena and processes that are expressed: economic efficiency, social efficiency and budgetary efficiency, and characteristics revealing the nature of the measured object: quantitative indicators and qualitative indicators; and also to make appropriate changes in the methodology for calculating the main indicators of the State Program. 